\title{
Menelusur Relasi Indikator Indeks Pembangunan Gender terhadap Pertumbuhan Ekonomi
}

\section{EcceS:}

\section{Economics Social and Development Studies}

\author{
Zulfa Miftha'ul Hidayah' ${ }^{1}$ \\ Farida Rahmawati ${ }^{2}$
}

\author{
Fakultas Ekonomi, Universitas Negeri Malang \\ Jl.Semarang No.5 Malang, Indonesia \\ E-mail: zulfamifthau@gmail.com ${ }^{1}$, farida.rahmawati.fe@um.ac.id ${ }^{2}$
}

(Article history) Received: 2020-05-27, Revised: 2020-05-31, Accepted: 2020-06-18

Available online: 2020-06-22, DOI: 10.24252/ecc.v7i1.13919

\section{Abstrak: Menelusur Relasi Indeks Pembangunan Gender Terhadap Pertumbuhan Ekonomi}

Kesetaraan gender memiliki relevansi terhadap perekonomian suatu negara. Dengan tercapainya keseteraan gender, semua warga negara memiliki akses yang sama untuk meningkatkan produktivitas dalam kegiatan perekonomian, baik produksi maupun konsumsi. Tujuan dari penelitian ini untuk mengidentifikasi apakah indikator Indeks Pembangunan Gender (IPG) mempengaruhi pertumbuhan ekonomi daerah. Indikator IPG dalam penelitian ini adalah Angka Harapan Hidup, Rata-rata Lama Sekolah dan Tingkat Partisipasi Angkatan Kerja. Sedangkan pertumbuhan ekonomi daerah tercermin pada nilai Produk Domestik Regional Bruto (PDRB). Dipilinnya Provinsi Jawa Timur sebagai unit analisis dikarenakan kinerja provinsi tersebut menunjukkan angka IPG yang masih berfluktuatif seiring tingkat pertumbuhan ekonomi yang cenderung mengalami peningkatan. Metode analisis menggunakan kuantitatif deskriptif dengan analisis regresi linier berganda model Ordinary Least Square (OLS). Hasil temuan menunjukan bahwa penurunan ketimpangan gender dalam aspek kesehatan dan pendidikan memiliki pengaruh positif terhadap meningkatnya pertumbuhan ekonomi provinsi Jawa Timur. Kesetaraan gender dalam hal peningkatan kualitas kesehatan dan pendidikan akan memacu tingginya produktivitas tenaga kerja sehingga meningkatkan pertumbuhan ekonomi. Pada variabel TPAK, ditemukan hasil penelitian yang menunjukkan bahwa kesetaraan gender pada aspek ketenagakerjaan tidak cukup mendorong pertumbuhan ekonomi provinsi Jawa Timur. Hal ini disebabkan oleh faktor internal kualitas tenaga kerja serta faktor eksternal dukungan kebijakan pemerintah dalam hal meningkatkan ketersediaan lapangan pekerjaan. Keterbatasan lapangan pekerjaan menjadi pekerjaan rumah bagi pemerintah Provinsi Jawa Timur. Implikasi dari 
penelitian ini, diperlukan perluasan lapangan kerja melalui pelatihan menjadi wirausaha sesuai dengan ciri khas daerah masing-masing sehingga nantinya akan mampu membuka lapangan pekerjaan secara mandiri dan mendorong peningkatan UMKM dan ekonomi lokal. Tindakan pemerintah dalam meningkatkan jiwa kewirausahaan melalui program pengembangan pesantren berbasis kewirausahaan juga SMA dan MA double track serta pendampingan terhadap wirausahawan muda.

Kata Kunci: Angka Harapan Hidup; Kesetaraan Gender; Rata-rata Lama Sekolah; Tingkat Partisipasi Angkatan Kerja

\section{Abstract: Tracing Gender Development Index Relations Towards Economic Growth}

Gender equality has relevance to a country's economy. With the achievement of gender equality, all citizens have equal access to increase productivity in economic activities, both production and consumption. The purpose of this study is to identify whether the Gender Development Index (IPG) indicator influences regional economic growth. The IPG indicators in this study are Life Expectancy, Average Length of School and Labor Force Participation Rate. While regional economic growth is reflected in the value of Gross Regional Domestic Product (GRDP). The choice of East Java Province as the unit of analysis is because the province's performance shows that IPG figures are still fluctuating as the level of economic growth tends to increase. The method of analysis uses descriptive quantitative analysis with multiple linear regression analysis Ordinary Least Square (OLS). The findings show that the decrease in gender inequality in health and education aspects has a positive influence on the increasing economic growth of the province of East Java. Gender equality in terms of improving the quality of health and education will spur high labor productivity thereby increasing economic growth. On the TPAK variable, research findings have been found that gender equality in labor aspects is not sufficient to encourage economic growth in the province of East Java. This is caused by internal factors of labor quality and external factors supporting government policies in terms of increasing the availability of jobs. Limited employment opportunities have become homework for the East Java Provincial Government. The implication of this research is that it is necessary to expand employment opportunities through training to become entrepreneurs in accordance with the characteristics of their respective regions so that later they will be able to open jobs independently and encourage the improvement of MSMEs and the local economy. The government's actions in enhancing the spirit of entrepreneurship through the entrepreneurship-based pesantren development program as well as high school and MA double tracks as well as mentoring young entrepreneurs.

Keywords: Average School Length Rate; Gender Equality; Labor Force Partcipation Rate; Life Expectancy Rate 


\section{PENDAHULUAN / INTRODUCTION}

Setiap negara bertujuan untuk meningkatkan pertumbuhan ekonomiguna mensejahterakan masyarakatnya. Secara umum, kesejahteraan mengacu pada kondisi dimana masyakarat memenuhi kebutuhan mereka, baik dalam kegiatan sosial maupun ekonomi (Patel et al., 2012). Salah satu dimensi mendasar dalam kesejahteraan ekonomi suatu masyarakat adalah kesetaraan, yang mengindikasikan bahwa seluruh masyarakat dapat menikmati hasil pembangunan, tanpa terkecuali. Mulasari (2015) menegaskan bahwasanya berkontribusi dalam pembangunan menjadi hak setiap individu, baik dilakukan secara langsung maupun tidak langsung. Lebih lanjut, menurut Widayanti, et al (2013) menyebutkan bahwasanya kesetaraan gender perempuan dan laki-laki adalah dimensi dasar dalam pembangunan manusia, pembangunan adalah pencapaian yang merata dan adil baik antar generasi, etnis, jenis kelamin maupun wilayah menjadi hal yang penting dalam proses pembangunan seperti salah satu kesepakatan bersama yang telah disepakati secara global. (Aktaria, 2012).

Gambar 1. Peringkat Kesetaraan Gender Indonesia

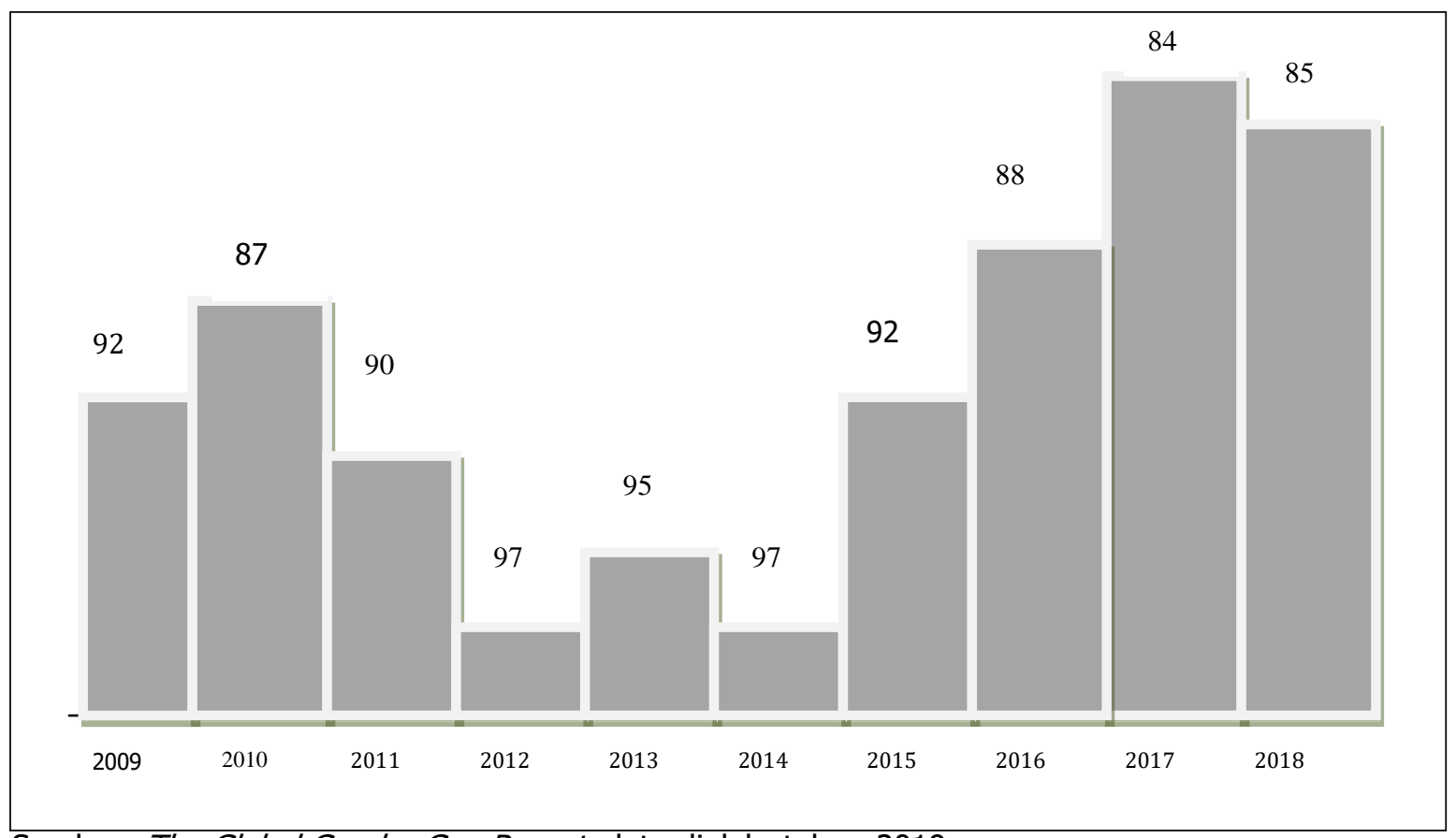

Sumber: The Global Gender Gap Report data diolah, tahun 2019 
Berdasarkan data yang dihimpun dari Hausman, et al (2019) menunjukkan bahwa peringkat Indonesia cenderung mengalami kenaikan selama beberapa tahun terakhir, mengindikasikan adanya keberhasilan pemerintah Indonesia dalam upaya menyetarakan laki-laki dengan perempuan untuk terlibat aktif dalam proses pembangunan. Pengukuran tersebut memuat beberapa dimensi penting, diantaranya dimensi pendidikan, kesehatan dan keterlibatan politik dari 145 negara yang disurvei. Pencapaian peringkat kesetaraan gender Indonesia selama satu dekade terakhir, dalam periode tahun 2009 - 2018 cukup fluktuatif.

Provinsi Jawa Timur memiliki sumber daya manusia melimpah, ditunjukkan dengan posisi provinsi ini sebagai provinsi berpenduduk terpadat di urutan kedua setelah Provinsi Jawa Barat, yakni sebanyak 39 juta jiwa per tahun 2018. Dengan tingkat kepadatan penduduk yang tinggi, pertumbuhan ekonomi yang dicapai oleh Jawa Timur pada tahun 2017 tumbuh sebesar 5,47\% dan menjadi 5,50\% pada tahun berikutnya. Namun demikian, bila dilihat dari indikator SDM yang diukur melalui perhitungan Indeks Pembangunan Manusia (IPM), maka tingkat IPM Provinsi Jawa Timur masih lebih rendah daripada enam provinsi lain di pulau jawa. Berikut adalah data perbandingan Indeks Pembangunan Gender (IPG) dengan Indeks Pembangunan Manusia (IPM) beberapa provinsi di pulau Jawa:

Gambar 2. Perbandingan IPG dan IPM di Pulau Jawa Tahun 2018

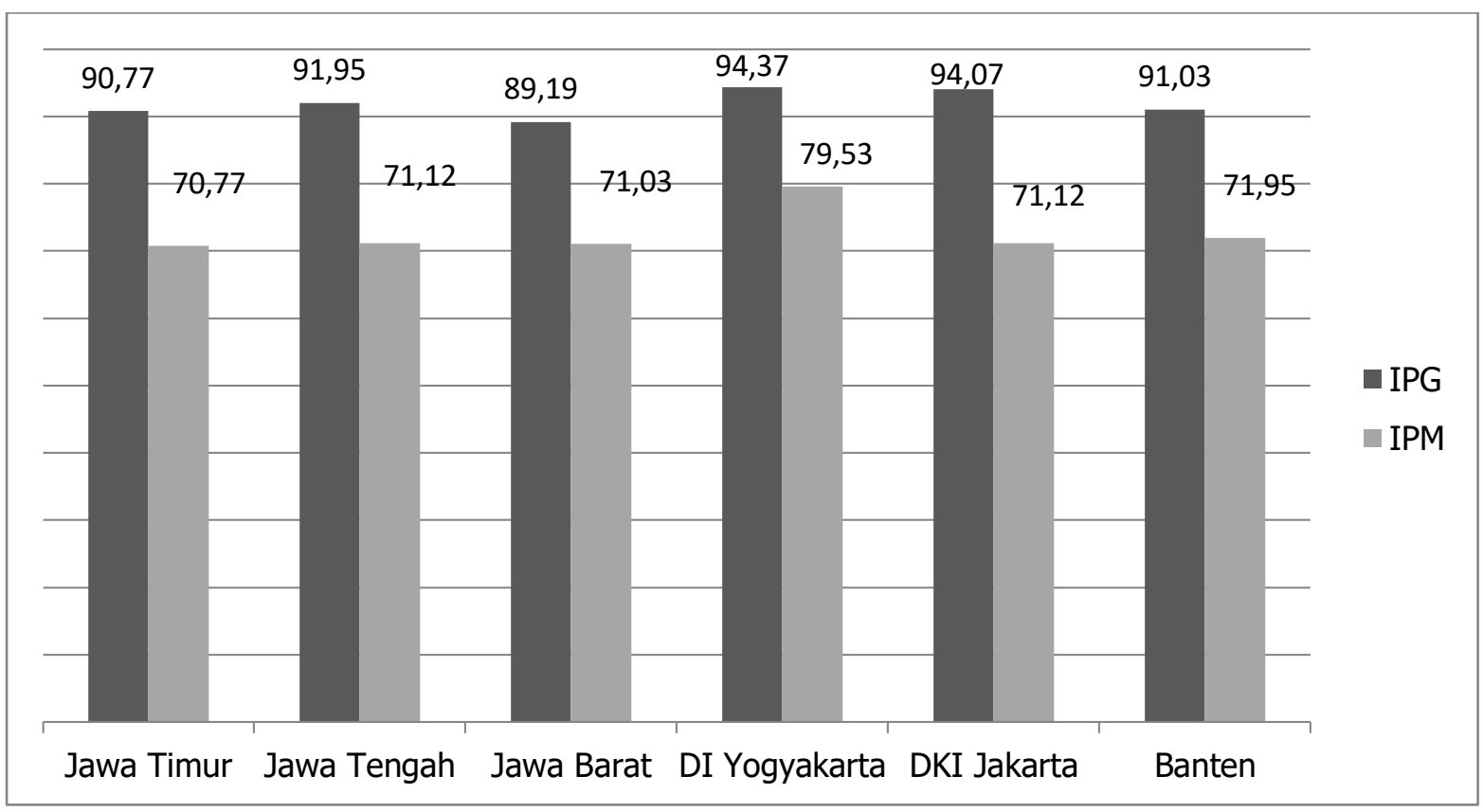

Sumber: Badan Pusat Statistik diolah, tahun 2019 
Kesetaraan gender diukur dari perbandingan angka IPM dan IPG, dimana kesetaraan gender akan tercapai apabila angka IPG mendekati angka 100 (Nazmi, 2018). Dari hasil perbandingan, apabila kenaikan angka IPG diikuti dengan kenaikan angka IPM maka dikatakan ketimpangan gender menurun, dan sebaliknya. Perbandingan angka IPM dan IPG, angka IPM yang lebih tinggi dari IPG menggambarkan ketimpangan gender sedangkan ketika IPM sama dengan IPG ketimpangan tidak terjadi. Di Provinsi Jawa Timur, angka Indeks Pembangunan Manusia (IPM) memiliki grafik yang meningkat dalam sepuluh tahun terakhir, namun kondisi ini berbanding terbalik dengan angka Indeks Pembangunan Gender (IPG) yang justru mengalami penurunan di tahun 2016. Penurunan ini terjadi disebabkan oleh beberapa hal diantaranya adanya indikasi penurunan kinerja oleh pemerintah dalam upaya penurunan ketimpangan gender di suatu daerah. Ketimpangan ini menunjukan adanya kondisi yang tidak setara antara pencapaian serta peran dari gender laki-laki dan perempuan dari beberapa bidang seperti pendidikan, kesehatan dan tenaga kerja.

Gambar 3. Perkembangan IPM dan IPG Provinsi Jawa Timur

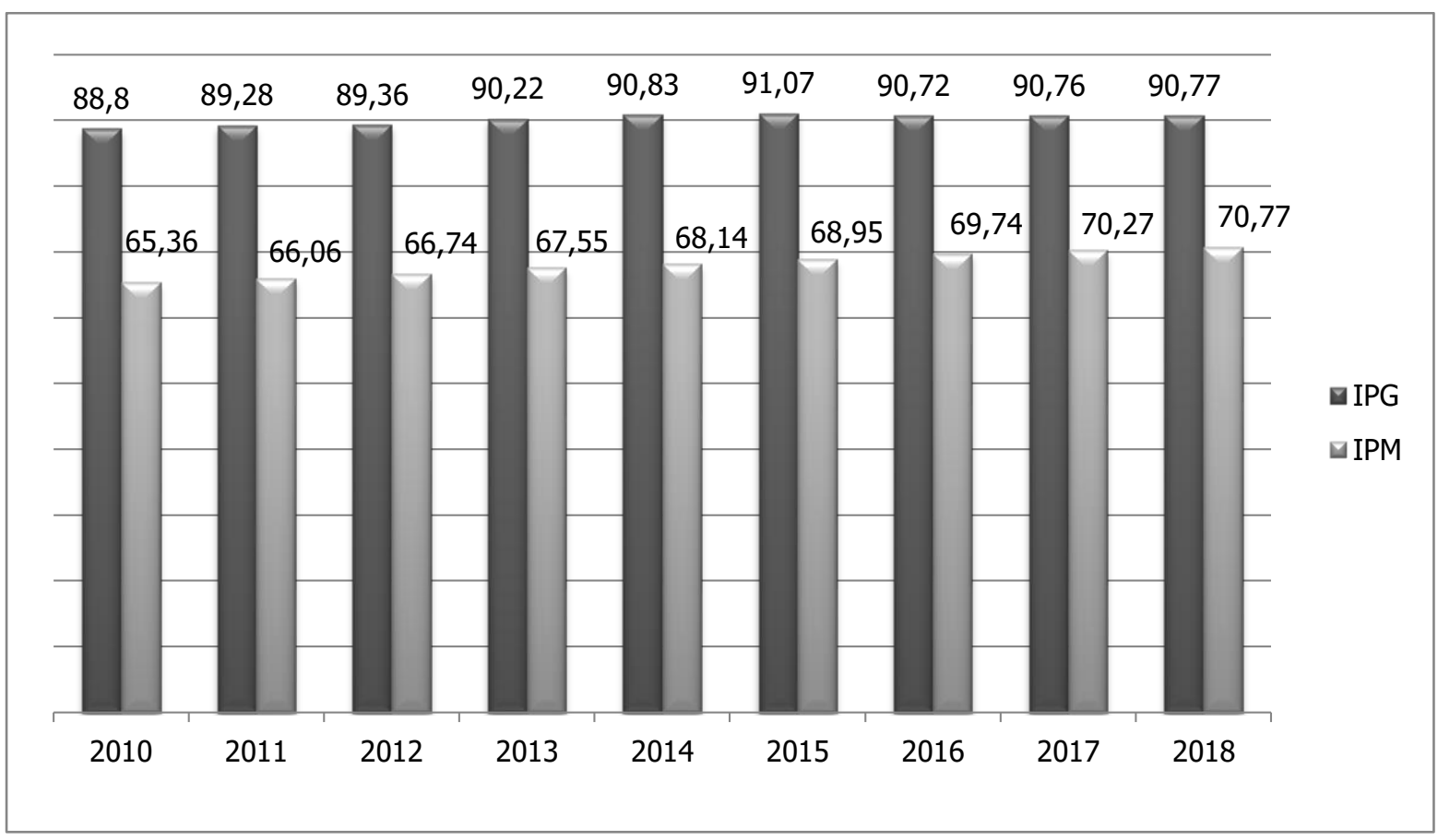

Sumber: Badan Pusat Statistik data diolah,tahun 2019

Gambar 3 menerangkan bahwa angka IPG di Provinsi Jawa Timur dalam satu dekade terakhir menunjukan peningkatan indeks. Peningkatan ini sebesar 0,24 di tahun 2015 114 
namun dilanjutkan dengan penurunan di tahun berikutnya sebesar 0,37 di tahun 2016 . Penurunan ini tidak sama dengan angka indeks pembangunan manusia yang mengalami peningkatan hingga tahun 2018. Pengukuran indikator IPG diukur dengan Rata-rata Lama Sekolah (RLS), Angka Harapan Hidup (AHH), Tingkat Partisipasi Angkatan Kerja (TPAK). Indikator dalam IPG lebih spesifik pada perbandingan capaian antara gender laki-laki dan perempuan. Perbandingan ini bertujuan melihat antara kesempatan hidup yang dimiliki oleh laki-laki dan perempuan. Perempuan mempunyai angka harapan hidup yang lebih lama dikarenakan oleh peran reproduktif yang dimilikinya sebagai seorang ibu.

Dari paparan diatas, terdapat adanya permasalahan dalam ketimpangan gender dimana pada tahun 2016 terjadi penurunan angka IPG yang tercermin dari ketimpangan di bidang pendidikan serta ketenagakerjaan antara laki-laki dan perempuan. Penurunan terebut tidak sebanding dengan IPM yang menunjukan peningkatan di tahun yang sama. Hasil penelitian dari Arora (2012) menyebutkan bahwa negara dengan pendapatan perkapita yang tinggi dikaitkan dengan rendahnya ketimpangan gender dan sebaliknya negara dengan pendapatan perkapita yang rendah dikaitkan dengan ketimpangan yang tinggi. Negara yang memiliki pendapatan perkapita yang tinggi membuka peluang bagi penduduknya demi mendapatkan hak dan kesempatan yang sama. Dalam penelitian ini menyebutkan sulitnya akses pada pendidikan dan kesehatan meyebabkan ketimpangan yang tinggi. Penelitian tersebut memiliki skala nasional sehingga tidak mampu melihat ketimpangan gender di lingkup yang lebih kecil. Oleh karena itu, dalam penelitian ini menggunakan lingkup provinsi yang lebih kecil, sehingga ketimpangan dapat terlihat lebih nyata. Penelitian ini bertujuan melihat pengaruh ketimpangan gender yang tercermin dalam IPG terhadap pertumbuhan ekonomi pada lingkup lebih kecil yaitu Provinsi Jawa Timur. Dalam hasil penelitian Fleisher et.al (2010) disebutkan bahwa sumberdaya manusia secara positif memberikan dampak positif terhadap ouput dan pertumbuhan produktivitas dalam lintas regional. Investasi modal manusia di daerah yang kurang berkembang akan mempengaruhi efisiensi dan pengurangan ketimpangan.

\section{TINJAUAN TEORITIK / LITERATURE REVIEW}

Pertumbuhan ekonomi digambarkan sebagai berkembangnya kegiatan perekonomian sehingga menyebabkan penambahan barang maupun jasa (Kuncoro, 2014). Selain modal uang, modal manusia juga memegang peranan penting dalam kegiatan perekonomian. 


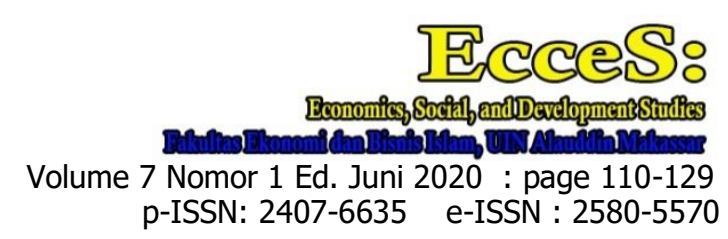

Modal manusia yang dimaksud di sini tidak hanya menyangkut soal kuantitas, namun yang lebih penting dari itu adalah kualitas. Artinya, modal manusia yang berkualitas diyakini dapat meningkatkan pertumbuhan output secara pesat. Sun'an (2015) mencoba menggambarkan bagaimana mekanisme berpengaruhnya modal terhadap tingkat output, baik pengaruh secara langsungnya maupun yang tidak langsung. Pengaruh langsung terhadap tingkat output terjadi karena pertambahan modal, baik modal uang ataupun modal manusia akan secara langsung meningkatkan pertumbuhan output. Pengaruh tidak langung disebabkan oleh semakin tingginya produktivitas tenaga kerja sehingga tenaga kerja tersebut akan semakin terspesialisasi. Spesialisasi tenaga kerja tersebut tentunya kan meningkatkan pertumbuhan output, karena pekerja akan bekerja secara lebih efektif dan efisien (Sun'an, 2015). Teori pertumbuhan Solow menerangkan bahwa pembangunan pada dasarnya lebih memberikan penekanan pada akumulasi modal sumberdaya manusia dikarenakan sumberdaya manusia memiliki peran penting sebagai agen pembangunan. Peran tersebut dilakukan melalui peningkatan pengetahuan, kesehatan serta nutrisi yang baik, termasuk keterampilan semuanya akan berpengaruh terhadap pertumbuhan ekonomi. Penelitian mengenai determinan pertumbuhan ekonomi telah banyak dilakukan, diantaranya oleh Vidyattama (2014), Aspiansyah, et al (2019) yang semuanya mengembangkan teori pertumbuhan Solow. Penelitian - penelitian tersebut memberikan penekanan pentingnya modal manusia dalam pertumbuhan ekonomi, sebagaimana yang dikemukakan oleh Solow pada tahun 1956. Aspiansyah, et al (2019) menyatakan bahwasanya investasi modal manusia memiliki peran sentral dalam meningkatkan pertumbuhan ekonomi regional baik dengan memasukan aspek keterkaitan antar wilayah maupun tidak. Bahkan, terjadi penurunan yang sangat signifikan ketika modal manusia tidak dimasukan dalam pertumbuhan ekonomi.

Perekonomian akan tumbuh mencapai keadaan stabil akan diikuti dengan pendapatan yang tinggi (Kuncoro, 2014). Pertumbuhan ini digambarkan dengan kenaikan atau penurunan secara angka yang dihitung setiap tahun. Pertumbuhan ekonomi secara nasional tercermin dalam PDB sedangkan secara regional tercermin didalam PDRB. PDRB menggambarkan seluruh nilai tambah riil yang dihasilkan dari aktivitas ekonomi suatu daerah. PDRB menggambarkan pendapatan suatu daerah, daerah dengan pendapatan yang tinggi berkaitan dengan pembangunan ekonomi yang baik. Pembangunan ekonomi 116 
mengandung unsur pembangunan sumberdaya manusia. Pendapatan daerah yang tinggi erat kaitannya dengan pembangunan sumberdaya manusia yang baik.

Berbeda dengan pandangan Arora (2012), pendapatan yang tinggi berkaitan dengan ketimpangan yang rendah. Pertumbuhan ekonomi tidak selalu diikuti dengan perbaikan ekonomi secara menyeluruh, akan tetapi justru seringkali dibarengi dengan ketimpangan. Ketimpangan ini seringkali dirasakan oleh kaum perempuan yang sulit mendapatkan akses baik kesehatan maupun pendidikan. Tidak menutup kemungkinan bahwasannya negara dengan tingkat pendapatan tinggi justru berhadapan dengan tingkat ketimpangan yang juga tinggi, disebabkan oleh rendahnya pendidikan perempuan yang menyebabkan perempuan diposisikan pada pekerja kasar yang menimbulkan tingginya ketimpangan gender di suatu wilayah. Ketimpangan gender dapat terlihat dari indeks pembangunan gender, yang didalamnya terdapat beberapa indikator untuk menilai ketimpangan gender di berbagai bidang (Harahap, 2012). Hasil kajian literatur menunjukan bahwa variabel angka harapan hidup menjadi indikator yang menggambarkan ketimpangan bidang kesehatan yang dialami perempuan. Perempuan memiliki kerentanan fisik yang lebih tinggi sehingga kesehatan perempuan menjadi prioritas yang dilakukan pemerintah guna meningkatkan kualitas sumberdaya manusia. Program pemerintah sejatinya tidak hanya diperuntukan bagi perempuan saja, pemerintah memberikan program kesehatan yang diperuntukan bagi lakilaki yang dilakukan guna meningkatkan taraf kesehatan masyarakat (Purba, 2016).

Menurut Nurwijayati (2017) pendidikan yang tinggi menjadikan seseorang dengan pengetahuan dan keterampilan yang tinggi sehingga mampu memproduksi barang maupun jasa untuk mendorong tingkat pertumbuhan ekonomi di suatu wilayah. Pendidikan bagi perempuan memiliki dampak tambahan yang positif, diantaranya penurunan pernikahan dini, tingkat kematian anak, serta pendidikan anak yang lebih tinggi. Hal ini dengan sendirinya akan mendorong perspektif pertumbuhan jangka panjang pada suatu negara/wilayah (Schober and Winter, 2011). Sejalan dengan peneltian Cuberes, et al (2011) menyatakan bahwa negara berkembang yang berpenghasilan rendah atau menengah tidak mampu berbuat banyak dalam hal pembangunan manusia. Perempuan dengan pendidikan menengah cenderung rendah memiliki kaitan dengan modal manusia yang rendah dimasa yang akan datang. Mereka cenderung mengalihkan biaya pendidikan ke biaya pengurusan anak. Pada saat yang sama, diskriminasi gender dalam pasar tenaga kerja menyebabkan inefisiensi dalam alokasi input serta menimbulkan kerugian. Penelitian Cuberes (2011) 
menunjukan bahwa ketidaksetaraan gender dalam pendidikan dapat mengurangi rata-rata modal manusia dan membahayakan kinerja perekonomian. Hal ini disebabkan negara kehilangan penduduk usia produktif nya yang seharusnya mampu aktif secara ekonomi dan membantu perekonomian negara.

Irfan (2012) perempuan rentan memiliki keterbatasan akses kedalam pendidikan, kesehatan dan peluang kerja. Mereka memiliki kepemilikan atas dirinya yang terbatas. Efek tidak langsung dari ketimpangan ini adalah tingkat kesuburan, tingkat kematian bayi dan pendidikan anak, tingkat kesuburan yang relatif rendah mampu memperlambat pertumbuhan populasi yang akan menurunkan beban ketergantungan yang pada gilirannya akan menyebabkan naiknya proporsi tabungan juga investasi. Menurut Sitorus (2016), peningkatan akses bagi pendidikan perempuan akan memberikan keuntungan bagi pertumbuhan ekonomi.

Hal ini terjadi apabila perempuan diprediksi memiliki tingkat pengembalian pendidikan yang relatif lebih tinggi dibandingkan dengan tingkat pengembalian pendidikan pada gender laki-laki. Fenomena seperti ini lazim ditemui di sejumlah negara berkembang. Dengan meningkatkan tingkat pendidikan perempuan tidak hanya akan meningkatkan produktivitas dirinya tetapi juga menurunkan fertilitas, memperbaiki kesehatan maupun gizi anak-anak. Seperti yang dipaparkan dalam penelitian Aktaria (2012) dimana pendidikan memberikan efek ganda (multiplier effect) terhadap generasi mendatang. Perempuan memungkinkan menanggung beban besar dalam kemiskinan, dengan memperbaiki peran serta status dari perempuan melalui bidang pendidikan akan berdampak kepada pemutusan lingkaran setan kemiskinan.

Variabel terakhir yang mewakili ketimpangan di bidang ketenagakerjaan yaitu TPAK, yakni menggambarkan seberapa besar angkatan kerja berpartisipasi didalam aktivitas perekonomian. Terjadinya ketimpangan dalam TPAK antara laki-laki dan perempuan membatasi perempuan untuk aktif secara ekonomi. Menurut Arora (2012) perempuan lebih banyak terjun didalam sektor informal yang didalam pekerjaannya tidak memerlukan keahlian yang khusus. Hal ini menyebabkan kecenderungan meskipun perempuan memiliki pekerjaan namun memiliki pendapatan yang rendah. 
Didalam sektor informal, dua fenomena yang terjadi ialah kesenjangan upah yang menyebabkan perempuan menerima gaji yang lebih rendah sebagai akibat dari rendahnya pendidikan seseorang. Ketimpangan pendidikan memiliki kaitan yang erat dengan ketimpangan pendapatan yang diterima peempuan (Harahap, 2012). Sektor industri pengolahan memiliki dominasi yang besar dalam pertumbuhan ekonomi di Jawa Timur sehingga, peranan tenaga kerja sebagai penggerak perekonomian memiliki pengaruh yang kuat dalam penyokong aktivitas perekonomian. Penurunan fertilitas perempuan dalam kemampuan mengukur ketimpangan gender mendatangkan keuntungan positif bagi penurunan beban ketergantungan terhadap angkatan kerja. Pemerataan kesempatan ini memberikan dampak positif bagi kemampuan pekerja perempuan dalam perdagangan internasionl. Dengan tingkat pendidikan perempuan yang tinggi maka perempuan dinilai lebih siap menghadapi tantangan global melalui mendapatkan pekerjaan yang layak.

\section{METODE PENELITIAN / RESEARCH METHODS}

Metode kuantitatif deskriptif dipilih menjadi metode dalam penelitian ini. Metode ini digunakan untuk membuktikan teori-teori terdahulu dengan meneliti objek secara lebih nyata, serta membuktikan hasil penelitian yang telah dilakukan sebelumnya serta membutikan bahwasannya diduga terdapat pengaruh antara variabel independent (RAHH, RRLS, RTPAK) terhadap variabel dependent (Pertumbuhan Ekonomi). Dalam memberikan gambaran yang lebih jelas mengenai fenomena yang sedang terjadi dipilih menggunakan deskriptif. Data sekunder menjadi data yang digunakan didalam penelitian. Data tersebut bersumber dari publikasi online BPS dan memilih populasi AHH laki-laki dan perempuan Provinsi Jatim 2009 - 2018, RLS perempuan dan laki-laki Provinsi Jatim 2009 - 2018, dan TPAK laki-laki dan perempuan Provinsi Jatim 2009 - 2018. Didalam penelitian ini, regresi linier berganda model OLS dengan data time series dipilih menjadi model penelitian.

$$
Y=\beta 0+\beta \operatorname{LnX} 1 t 1+\beta \operatorname{LnX} t 2+\beta \operatorname{LnXt3}+\ldots \ldots .+e
$$

Dimana Y: pertumbuhan ekonomi Provinsi Jatim (\%), $\beta 0$ : Konstanta, $\beta n$ : koefisien regresi, Ln : logaritma natural, Xt1: rasio $\mathrm{AHH}$ perempuan dan laki-laki (\%), Xt2 : rasio RRLS laki-laki dan perempuan (\%), Xt3: rasio TPAK perempuan dan laki-laki (\%), T: time series tahun 2009 - 2018, E: error. 


\section{HASIL DAN PEMBAHASAN / RESULT AND DISCUSSION}

Tabel 1. Hasil Regresi Linier Berganda Variabel Rasio AHH, Rasio RLS dan Rasio TPAK Terhadap Pertumbuhan Ekonomi Provinsi Jawa Timur Tahun 2009 - 2018

Variabel Koefisien Std. Error t-Statistic Prob.

\begin{tabular}{|c|c|c|c|c|}
\hline C & $-68764,49$ & 11785,27 & $-5,834784$ & 0,0011 \\
\hline $\begin{array}{c}\text { Rasio Angka Harapan } \\
\text { Hidup }\end{array}$ & 1,456397 & 2504,134 & 5,815969 & 0,0011 \\
\hline $\begin{array}{l}\text { Rasio Rata-rata Lama } \\
\text { Sekolah }\end{array}$ & 2,153213 & 28,61386 & 7,525070 & 0,0003 \\
\hline $\begin{array}{c}\text { Rasio Tingkat } \\
\text { Partisipasi Angkatan } \\
\text { Kerja }\end{array}$ & $-11,24130$ & 17,78734 & $-0,631983$ & 0,5507 \\
\hline R-squared & 0,917711 & & & \\
\hline Adjusted R-squared & 0,876566 & & & \\
\hline S.E. of regression & 0,866939 & & & \\
\hline Sum squared resid & 4,509497 & & & \\
\hline Log likelihood & $-10,20739$ & & & \\
\hline F-statistic & 22,30448 & & & \\
\hline Prob(F-statistic) & 0,001181 & & & \\
\hline
\end{tabular}

Sumber : E-views data diolah, tahun 2019

\section{Pengaruh Rasio Angka Harapan Hidup Terhadap Pertumbuhan Ekonomi}

Hasil penelitian menunjukan bahwasannya rasio AHH memiliki pengaruh positif yang digambarkan pada koefisien regresi yang positif pula yaitu sebesar 1,456397 serta memiliki probabilitas sebesar 0,001 yang dimana angka ini kurang dari (a) atau taraf kesalahan yang sebesar 5\% atau 0,05. Artinya dalam penelitian ini angka harapan hidup memiliki pengaruh yang positif dan signifikan dimana ketika terjadi peningkatan rasio $\mathrm{AHH}$ sebesar $1 \%$ akan berpengaruh pada peningkatan pertumbuhan ekonomi sebesar $1,45 \%$. Kenaikan rasio $\mathrm{AHH}$ menggambarkan semakin kecil nya ketimpangan kesehatan antara penduduk laki-laki dan perempuan. Penurunan ketimpangan ini mengindikasikan keberhasilan pemerintah dalam upaya mewujudkan kesetaraan gender dibidang kesehatan melalui berbagai program yang 120 
telah dilakukan guna meningkatkan taraf kesehatan penduduknya. Penurunan angka ini digambarkan pada perbandingan $\mathrm{AHH}$ kedua nya, didalam grafik nya terjadi peningkatan AHH kedua nya laki-laki dan perempuan.

Angka terebut mencerminkan hasil kinerja pemerintah dan keberhasilan program pembangunan manusia dibidang kesehatan melalui upaya preventif dan kuratif. Upaya upaya ini meliputi Gerakan Masyarakat Hidup Sehat (GERMAS) yang dilakukan yang memiliki tujuan untuk mendorong masyarakat memiliki kesadaran untuk menjaga kualitas hidup dan lingkungan yang lebih sehat, selain itu upaya lain dilakukan melalui pemberian pengobatan gratis, sosialisasi program penanggulangan penyakit, perbaikan fasilitas dan pelayanan kesehatan. Sejalan dengan Muda (2019) yang hasil penelitiannya menunjukan dimana tingkat kesehatan berpengaruh positif terhadap perekonomian suatu wilayah, kesehatan memiliki peranan penting pada kualitas sumberdaya manusia yang berdampak besar dalam produktivitas, efisien dan inisiatif seseorang. Harapan hidup yang semakin tinggi mencerminkan semakin terbuka nya kesempatan dan akses bagi perempuan dalam kontribusinya kepada perekonomian Jatim.

Menurut BPS Provinsi Jatim Tahun 2017, penduduk perempuan memiliki penduduk usia kerja sebanyak 15,57 juta jiwa dengan pembagian dimana perempuan yang masuk kedalam golongan angkatan kerja sebanyak $54,37 \%$ dimana yang aktif secara ekonomi/memiliki pekerjaan sebanyak 52,36\% dan sisanya sebanyak 2,01\% merupakan pengangguran. Angka tersebut menunjukan bahwa penduduk yang tergolong angkatan kerja perempuan memiliki produktifitas yang tinggi pada usia produktif mereka. Sedangkan penduduk angkatan kerja laki-laki yang aktif secara ekonomi sebanyak 12.074.000 jiwa sedangkan sebanyak 526.000 jiwa menganggur. Dapat disimpulkan bahwa tingkat kesehatan yang baik akan meningkatkan produktivitas seseorang melalui peningkatan aktivitas ekonomi mereka jika dilihat dari peningkatan angkatan kerja yang aktif secara ekonomi. Meningkatkan pendapatan daerah di suatu wilayah juga disebabkan oleh peningkatan produktivitas masyarakatnya dengan cara memproduksi barang dan jasa yang berdampak peningkatan PDRB daerah tersebut. Hasil penelitian menunjukan hasil yang sebaliknya yang dilakukan oleh Handayani (2016) dimana dalam penelitiannya AHH tidak berpengaruh terhadap perekonomian suatu wilayah. Hal ini memungkinkan terjadi ketika kenaikan harapan hidup tidak diikuti dengan keahlian pemerintah sehingga akan menjadikan beban dalam pembangunan daerah. 


\section{Pengaruh Rasio Rata-Rata Lama Sekolah Terhadap Pertumbuhan Ekonomi}

Hasil estimasi regresi linier berganda dapat terlihat bahwa rasio RLS memiliki pengaruh positif yang tercermin dalam koefisien regresi yang positif pula sebesar 2,153213 dan dengan probabilitas sebesar 0,003 yang angka ini kurang dari (a) atau taraf kesalahan dalam penlitian sebesar 5\% atau 0,05. Hal ini berarti penelitian ini RLS memiliki pengaruh positif signifikan terhadap pertumbuhan ekonomi Provinsi Jatim. Peningkatan rasio menggambarkan penurunan ketimpangan pendidikan perempuan maupun laki-laki. Apabila kondisi demikian dapat terus ditekan serta didukung dengan program pemerintah dalam memberikan akses bagi penduduk untuk mendapat kesempata yang sama dalam menempuh pendidikan, maka program pemerintah dalam upaya peningkatan kualitas sumberdaya manusia menunjukan hasil yang signifikan.

Asumsi secara umum apabila semakin tingginya pendidikan yang berhasil ditamatkan oleh seseorang maka orang tersebut mendapatkan pengetahuan serta keterampilan yang lebih tinggi dibandingkan dengan seseorang dengan pendidikan yang lebih rendah. Asumsi lain menyebutan ketika pendidikan yang lebih tinggi memberikan kemampuan seseorang untuk mengambil keputusan yang dinilai lebih rasional (Muda, 2019). Produktivitas seseorang yang tinggi menggambarkan semakin tinggi pendidikan yang telah ditempuh.

Menurut data BPS Provinsi Jatim tahun 2018, penduduk perempuan dan laki-laki yang berhasil menamatkan pendidikan tinggi meningkat setiap tahun nya. Sebagai gambaran dimana perempuan yang berhasil tamat pendidikan tinggi sebanyak 800.000 jiwa tahun 2018 yang angka ini meningkat jika disandingkan dengan tahun sebelumnya yang hanya 739.000. Laki-laki pun demikian, sebanyak 969.000 penduduk laki-laki berhasil tamat pendidikan tinggi yang juga menunjukan peningkatan tahun sebelumnya yang hanya 936.000 jiwa. Peningkatan ini berdampak pada posisi kedua nya dalam bidang pekerjaan. Dari pembagian tujuh sektor pekerjaan oleh BPS, angkatan kerja perempuan mendominasi profesi tenaga usaha jasa, professional serta teknisi. Sedangkan angakatan kerja laki-laki mendominasi profesi tenaga kepemimpinan dan ketatalaksanaan. Kondisi demikian mendorong kemungkinan peningkatan pada perekonomian Jatim yang mencapai 5,5\% di tahun 2018. Hal ini disebabkan dominasi kontribusi pada sektor - sektor industri akan membutuhkan banyak tenaga kerja di dalamnya baik tenaga kerja kasar hingga 
professional. Penelitian serupa yang mendukung hasil penelitian ini adalah Nurwijayati (2017) dimana hasil penelitian menunjukan pendidikan mempengaruhi kondisi modal manusia dengan kapasitas yang baik untuk mendorong adanya peningkatan kemampuan produksi barang serta jasa secara langsung ataupun tidak langsung berdampak kepada pertumbuhan ekonomi suatu daerah. Kemampuan, kualitas, bakat, sikat, kecakapan, nilai, tujuan motivasi serta strutur politik menjadi penentu utama dalam upaya meningkatkan pertumbuhan ekonomi (Jhingan dalam Nurwijayati, 2017).

Hasil temuan dalam penelitian ini bertentangan dengan yang dilakukan oleh Putri, dkk (2016) dimana dalam hasil temuannya tingkat pendidikan tidak berpengaruh terhadap pertumbuhan ekonomi. Kondisi ini disebabkan oleh penentu tingkat pendidikan yang diukur dengan tingkat tamanan pendidikan SLTA. Dimana tamatan pendidikan SLTA harus berjuang untuk bersaing dengan seseorang yang tamat pendidikan lebih tinggi/ jenjang pendidikan tinggi. Oleh karenanya, tingkat pendidikan tidak berpengaruh terhadap pertumbuhan ekonomi

\section{Pengaruh Rasio Tingkat Partisipasi Angkatan Kerja Terhadap Pertumbuhan Ekonomi}

Hasil penelitian menunjukan bahwasannya rasio TPAK memiliki pengaruh negatif yang digambarkan pada koefisien regresi yang negatif pula yaitu sebesar 11,24 serta memiliki probabilitas sebesar 0,5507 yang dimana angka ini lebih dari (a) atau taraf kesalahan yang sebesar $5 \%$ atau 0,05 . Artinya dalam penelitian ini rasio TPAK memiliki pengaruh yang negatif serta tidak signifikan dimana ketika terjadi peningkatan rasio TPAK sebesar $1 \%$ akan berpengaruh negatif yang justru menurunkan pertumbuhan ekonomi pada level 11,24\%. Meningkatkan partisipasi ini membuka kesempatan bagi penduduk usia kerja dalam masuk ke pasar tenaga kerja. Ketimpangan yang ada digambarkan dalam kesenjangan tingkat partisipasi kedua nya, perempuan mempunyai TPAK yang rendah jika dibandingkan laki-laki. Peningkatan ini memberikan peluang bagi para angkatan kerja perempuan untuk aktif secara ekonomi/bekerja.

Meningkatnya jumlah tenaga kerja wanita sejatinya mampu menggerakan aktivitas perekonomian yang akan memacu pertumbuhan ekonomi, namun jika dilihat dari hasil estimasi terlihat bahwa kenaikan partisipasi angkatan kerja mampu menyebabkan penurunan pertumbuhan ekonomi. Penelitian Safitri (2019) dimana penduduk yang semakin 
bertambah jika tidak diimbangi dengan persediaan lapangan pekerjaan akan menimbulkan pengangguran yang menyebabkan penurunan produktivitas seseorang. Dampak dari pengangguran sendiri secara tidak langsung akan menyebabkan penurunan pendapatan perkapita yang jika ditelaah lebih jauh akan berdampak pada penurunan pertumbuhan ekonomi. Persediaan lapangan pekerjaan sejatinya berbanding lurus dengan penambahan angkatan kerja.

Pemerintah yang tidak sigap dengan penambahan ini akan mengahadapi gelombang pengangguran yang bertambah bertambah yang secara tidak langsung akan berdampak pada pengurangan keuntungan daerah yang disebabkan kurangnya lapangan pekerjaan sehingga angkatan kerja tidak mampu melakukan kegiatan perekonomian. Menurut BPS Provinsi Jawa Timur tahun 2018, angkatan kerja perempuan didominasi pada kelompok usia prima (25 - 54 tahun) dengan persentasi mencapai 67,41\%. Peningkatan angkatan kerja yang produktif semakin bertambah. Walaupun terjadi peningkatan kontribusi angkatan kerja setiap tahunnya, BPS mencatat TPT Jatim sebesar 3,99\% atau sebanyak 851.000 jiwa menjadi pengangguran.

Disimpulkan bahwasannya peningkatan rasio TPAK tidak memberikan hasil yang positif bagi perekonomian apabila kurang diimbangi dengan persediaan lapangan kerja oleh pemerintah akan menimbulkan pengangguran, dimana pengangguran tersebut akan menurunkan produktivitas seseorang. Seseorang yang tidak produktif tidak mampu menghasilkan barang dan jasa yang mampu menggerakan perekonomian. Sehingga akan menurunkan pendapatan daerah yang berdampak pada penurunan pertumbuhan ekonomi. Hasil penelitian Mohseni (2016) menyatakan dimana pengendalian inflasi dan pengurangan pengangguran melalui efisiensi penggunaan tenaga kerja berpengaruh dalam upaya peningkatakn kinerja perekonomian. Inflasi yang berkepanjangan serta pengangguran dapat menjadi beban daerah oleh karenanya, otoritas pemerintahan perlu melakukan pengendalian atas keduanya. Temuan dalam penelitian ini tidak sejalan dengan yang dilakukan oleh Purnama (2015) dimana pengangguran tidak berpengaruh terhadap pertumbuhan ekonomi disebabkan oleh faktor - faktor lain yang lebih memiliki pengaruh terhadap pertumbuhan ekonomi di suatu wilayah. 


\section{KESIMPULAN / CONCLUSION}

Ketimpangan gender mempengaruhi pertumbuhan ekonomi, terutama ketimpangan dalam bidang kesehatan dan bidang pendidikan. Ketimpangan bidang kesehatan tercermin dalam Rasio $\mathrm{AHH}$ berpengaruh positif dan signifikan terhadap pertumbuhan ekonomi Provinsi Jatim tahun 2009 - 2018. Kondisi ini menunjukan bahwa ketika rasio $\mathrm{AHH}$ mengalami peningkatan (mengindikasikan ketimpangan bidang kesehatan menurun) akan akan mendorong perekonomian Jatim yang meningkat. Ketimpangan bidang pendidikan tercermin dalam rasio RLS berpengaruh positif dan signifikan terhadap pertumbuhan ekonomi Provinsi Jatim tahun 2009 - 2018. Kondisi ini menunjukan apabila rasio RLS meningkat (mengindikasikan ketimpangan bidang pendidikan menurun) maka akan mendorong peningkatan perekonomian Provinsi Jatim. Ketidaksetaraan di bidang ketenagakerjaan tercermin dalam rasio TPAK berpengaruh negatif serta tidak signifikan terhadap pertumbuhan ekonomi Provinsi Jatim tahun 2009 - 2018. Kondisi ini menunjukan apabila rasio TPAK meningkat (mengindikasikan ketimpangan bidang ketenagakerjaan menurun) akan mendorong penurunan perekonomian Provinsi Jatim. Hal ini terjadi disebabkan oleh tidak tersedianya lapangan pekerjaan yang mampu menampung tenaga kerja baik laki-laki maupun perempuan secara proporsional. Saran yang mampu diberikan adalah pemerintah hendaknya lebih memberi perhatian terhadap ketimpangan gender di Provinsi Jawa Timur yang masih dinilai tinggi. Ketimpangan yang terjadi akibat dari tidak meratanya pembangunan manusia serta akses terhadap beberapa aspek pembangunan manusia seperti kesehatan, pendidikan dan ketenagakerjaan. Ketimpangan ini dapat diturunkan apabila pemerintah mampu memberikan akses yang sama baik dalam fasilitas kesehatan yang memadai bagi perempuan melalui sosialisasi penurunan angka kematian ibu dan anak, selain itu pemberian akses terhadap pendidikan perempuan yang juga masih dinilai rendah, pelebaran akses ini didukung dengan program beasiswa bagi penduduk miskin di daerah tertinggal yang dinilai memiliki penduduk perempuan yang minim dengan pendidikan. Disamping itu, perluasan lapangan pekerjaan yang diharapkan oleh angkatan kerja yang bertambah setiap tahun nya. Program- program pemerintah untuk meningkatkan jiwa kewirausahaan bagi calon pencari kerja akan sangat membantu pemerintah dalam menekan angka pengangguran baik laki-laki maupun perempuan. Program ini diharapnkan mampu mendorong seseorang untuk membuka lapangan pekerjaan sendiri melalui dunia wirausaha agar tidak sepenuhnya bergantung pada lapangan pekerjaan yang ada. Program tersebut diantaranya SMA dan MA double track yang mana dengan program ini, siswa nya 
dididik untuk memiliki jiwa wirausaha sejak dini sehingga ketika mereka saat lulus tidak bisa melanjutkan pendidikan yang lebih tinggi, diharapkan mereka mampu membuka lapangan pekerjaan sendiri.

\section{DAFTAR PUSTAKA / REFERENCES}

Aktaria, E.,\& Handoko, B. S. 2012. Ketimpangan Gender Dalam Pertumbuhan Ekonomi. Jurnal Ekonomi Pembangunan: Kajian Masalah Ekonomi dan Pembangunan, 13 (2), 194

Arora, Rashmi Umesh. 2012. Gender Inequality, Economic Development and Globalization: A State Level Anaysis of India. The Journal of Developing Areas Vo. 46 No. 1 pp 147 164

Aspiansyah, A., \& Damayanti, A. 2019. Model Pertumbuhan Ekonomi Indonesia: Peranan Ketergantungan Spasial. Jurnal Ekonomi Dan Pembangunan Indonesia, 19(1), 62-83. https://doi.org/10.21002/jepi.v19i1.810

Badan Pusat Statistik. 2019. Indeks Pembangunan Manusia Menurut Provinsi 2010-

2018. Available at: https://www.bps.go.id/dynamictable/2019/04/16/1615/peringkatindeks-pembangunan-manusia-menurut-provinsi-2010-2018-metode-baru-.html (Diakses pada: 05 Februari 2020)

Badan Pusat Statistik. Metadata Indikator Angka Harapan Hidup. Available at: https://sirusa.bps.go.id/sirusa/index.php/indikator/48 (Diakses pada: 05 Februari 2020)

Badan Pusat Statistik. Metadata Indikator Rata-rata lama sekolah. Available at: https://sirusa.bps.go.id/sirusa/index.php/indikator/572 . (Diakses pada 05 Februari 2020)

Badan Pusat Statistik. Metadata Indikator Tingkat Partisipasi Angkatan Kerja. Available at: https://sirusa.bps.go.id/sirusa/index.php/indikator/51 (Diakses pada 05 Februari 2020) 
Bappenas. 2012. Indeks Kesetaraan dan Keadilan Gender \& Indikator Kelembagaan Pengarustutamaan Gender. Jakarta: Kementrian Perencanaan Pembangunan Nasional

BPS Jawa Timur. 2018. Keadaan Angkatan Kerja Provinsi Jawa Timur Agustus 2018. Surabaya: Badan Pusat Statistik Provinsi Jawa Timur

Cuberes, David, and Teignier Marc. 2011. Gender Inequality and Economic Growth. World Development Report Background Paper 2012

Dinas Kesehatan Provinsi Jawa Timur. Profil Kesehatan Jawa Timur 2017. Available at:

https://www.kemkes.go.id/resources/download/profil/PROFIL KES PROVINSI 2017/ 15 Jatim 2017.pdf (Diakses pada: 19 Desember 2019)

Fleisher, B., Li, H., \& Zhao, M. Q. 2010. Human capital, economic growth, and regional Inequality in China. Journal of development economics, 92 (2), 215-231

Handayani, Sri. IKG Bendesa. Ni Nyoman Yuliarmi. 2016. Pengaruh Jumlah Penduduk, Angka Harapan Hidup, Rata rata lama sekolah dan PDRB Perkapita Terhadap Pertumbuhan Ekonomi di Provinsi Bali. E-Jurnal Fakultas Ekonomi dan Bisnis Universitas Udayana

Harahap, Rahmi FA. 2014. Analisis Pengaruh Ketimpangan Gender Terhadap Pertumbuhan Ekonomi Provinsi Jawa tengah. (Skripsi). UNDIP: Semarang

Hausman, Ricardo. Laura . D. Tyson. Sadia Zahidi . 2019. The Global Gender Gap Report 2018. Switzerland. World Economic Forum

Irfan, M., \& Amatul, R. 2012. Munich Personal Repec Archive Gender Inequality And Economic Growth: A Time Series Analysis For Pakistan Gender Inequality And Economic Growth: A Time Series. 37176.

Kementrian Pemberdayaan Peempuan dan Perlindungan Anak. 2018. Pembangunan Manusia Berbasis Gender 2018. Available at: https://www.kemenpppa.go.id/lib/uploads/list/6a89b-buku-pmbg-2018.pdf (Diakses pada 19 Desember 2019)

Kuncoro, Mudrajad. 2014. Ekonomi Pembangunan. Jakarta: Penerbit Erlangga 
Mohseni, M., \& Jouzaryan, F. 2016. Examining the Effect of Inflation and Unemployment on Economic Growth in Ira (1996 - 2012). Procedia Economics and Finance, 36 (16), 381 389

Muda, Riyan., \& Rosalina Koleangan. 2019. Pengaruh Angka Harapan Hidup, Tingkat Pendidikan dan Pengeluaran Perkapita Terhadap Pertumbuhan Ekonomi di Sulawesi Utara 2003 - 2017. Jurnal Berkala IImian Efisiensi Vo. 19 No.1 Tahun 2019

Mulasari, Frestiana Dyah. 2015. Peran Gender Perempuan Terhadap Pertumbuhan

Ekonomi Provinsi Jawa Tengah Tahun 2008 - 2012. Jurnal Ekonomi Pembangunan ISSN 2252-6765

Nazmi, Lisa. Abd Jamal. 2018. Pengaruh Ketimpangan Gender Terhadap

Pertumbuhan ekonomi di Indonesia. Jurnal IImiah Mahasiswa ekonomi Pembangunan Faakultas Ekonomi dan Bisnis Unsyiah Vo.3 No. 4 November 2018 : 740 - 750

Nurwijayati, Nita. 2017. Pengaruh Indikator Komposit Pembangunan Manusia

Terhadap Pertumbuhan Ekonomi Kabupaten/Kota Provinsi DIY. Jurnal Pendidikan dan Ekonomi Vol. 6 No. 6 Tahun 2017

Patel, L., Kaseke, E., \& Midley, J. 2012. Indogenous Welfare and Community-Based Social Development: Lessons from African Einnovations. Journal of Community Practice. 20 $(1-2), 12-31$

Purba, Ulung. 2016. Analisis Pengaruh Ketimpangan Gender Terhadap

Pertumbuhan Ekonomi di Provinsi Lampung. (Skripsi). Universitas Lampung: Lampung

Purnama, N. I. (2015). Analisis Pengaruh Pertumbuhan Ekonomi Terhadap Tingkat Pengangguran di Kota Medan Tahun 2000-2014. Jurnal Ekonomikawan, 15, 69-76.

Putri, I. A., \& Soesatyo, Y. 2016. Pengaruh Tingkat Pendidikan Dan Tingkat Pengangguran Terhadap Pertumbuhan Ekonomi Kota Surabaya. Jurnal Pendidikan Ekonomi (JUPE), $4(3), 1-7$.

Safitri, Aisyah. Ariusni. 2019. Pengaruh Kinerja Keuangan Daerah, Tingkat Partisipasi Angkatan Kerja, Dan Inflasi Terhadap Pertumbuhan Ekonomi Di Sumatera Barat. Jurnal Kajian Ekonomi dan Pembangunan Vol.1 No.2 
Zulfa, Farida ,Menelusur Relasi Indeks Pembangunan Gender...

Sitorus, Agnes Vera Yanti. 2016. The Impact Of Gender Inequality On Economic Growth In Indonesia: Jurnal Sosio Informa Vol. 2, No. 01, Januari - April, Tahun 2016. Kesejahteraan Sosial

Schober, T., \& Winter-Ebmer, R. 2011. Gender wage inequality and economic growth: Is there really a puzzle?-A comment. World Development, 39 (8), 1476-1484

Sun'an, Muammil. 2015. Ekonomi Pembangunan. Jakarta: Mitra Wacana Media

Vidyattama, Y. 2014. Issues in Applying Spatial Autocorrelation on Indonesia's Provincial Income Growth Analysis. Australasian Journal of Regional Studies, 20(2), 375-402.

Widayanti, Dara Veri., Rachman N.S.I., \& Mauretya Widya. 2013. Pengaruh Pertumbuhan Ekonomi Terhadap Kesenjangan Upah Gender. Proceeding PESAT (Psikologi, Ekonomi, Sastra, Arsitektur \& Teknik Sipil) Vol. Proceeding PESAT (Psikologi, Ekonomi, Sastra, Arsitektur \& Teknik Sipil) Vol. 5 Oktober 2013. ISSN 1858-2559 